\title{
Bullying of eighth graders in Slovenian primary schools (Secondary analysis of ICCS 2016)
}

Špela Javornik, Plamen Mirazchiyski and Nada Trunk Širca

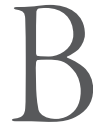

ullying has been a matter of concern for a long time, one of the first authors writing about that issue was Olweus (1997, p. 496), who exposed three main criteria for bullying. The first criteria characterizing bullying is "aggressive behavior or intentional harm doing", secondly, bullying is "repeatedly and over time" and third, "in an interpersonal relationship characterized by an imbalance of power". Authors in literature argue, that students who were bullied and also bully, »reported low academic achievement, loneliness, and psychosocial maladjustment « (Nansel et al. 200I; in Dorio et al., 2019).

Some studies found bullying others to be associated with low SES, including economic disadvantage, poverty, and low parental education. Additionally, where composite measures have been used, children from low socioeconomic backgrounds have been found to bully others slightly more often. (Tippett and Wolke, 2014, p. 48).

Bullying affects the climate in classroom and school and it has an impact on relationships among students, the relationship between bullying and the school climate is actually reciprocal (Brandyopathyay et al., 2009; Golstein et al., 2008, in Pečjak and Pirc, 2017, p. 76).

The main goal of this study is to research bullying in the eighth grade in Slovenian schools, how often they are bullied, the relationship with SES and background and contextual factors. The study will test if Slovenian eighth-graders with lower socio-economic status (SES) tend to be more frequently exposed to peer violence than the ones with higher SES and how is peer violence connected to different contextual factors that 
can be found in contextual questionnaires of the International Civic and Citizenship Education Study (ICCS) 2016.

\section{Theoretical framework}

Kristančič (2002, p. 97) defined violence as "a symptom of aggressive and hostile activities of individual groups and their members". He describes aggression as "all activities executed so as to cause damage to another person, animals and inanimate objects" (ibid., 98). ${ }^{\mathrm{I}}$ Merrell et. al. (2008, p. 26) defined bullying

as repeated acts of aggression, intimidation, or coercion against a victim who is weaker than the perpetrator in terms of physical size, psycholog$\mathrm{ical} /$ social power, or other factors that result in a notable power differential.

There are different divisions of peer violence among researchers. Olweus (1993, in Pečjak, 2014) distinguishes between direct peer violence (overt assault on a person) and indirect bullying (social isolation and exclusion). Sullivan (201r) divides bullying into physical (beat with injury, deliberate kicking, stripping, lashing, restraining, biting, overthrowing, pushing, deliberately damaging an individual's property or destroying his or her personal objects) and psychological violence (assaulting an individual's interior). Mental violence is further divided into verbal and non-verbal violence (direct non-verbal, indirect non-verbal and/or relational violence).

Berger (2007, in Pečjak, 2014) conducted a survey reviewing contributions to peer violence and summarized four main categories: physical violence (urging, kicking, damaging property of another), relational violence (manipulation of interpersonal relationships), verbal violence (teasing) and online bullying (spreading rumors online or sending offensive phone messages). Bučar Ručman (2009, in Javornik and Klemenčič, 2019) claims that there are three main categories of violence among students in school; physical, psychical and sexual violence. There is a connection between social conditions and delinquency of students, which many studies have shown.

Daniels (2017, p. 2) summarized three main forms of bullying; overt bullying, covert bullying and cyberbullying. For boys the most common forms are physical bullying and harassment, which is part of overt bullying. Studies found verbal violence more among girls, for example name-calling or making gestures, spreading rumors, excluding an indi- 
vidual, which is a part of covert bullying. Text messaging, posting photos of someone on the internet are known as cyberbullying. Overall, the most frequent form of bullying is verbal bullying and the least common form of violence is physical violence (Marsh et al., 20ır; Polak et al., 2orı; Wang, Iannotti and Nansel, 2009, in Pečjak and Pirc, 2017, p. 75). Cyberbullying is increasing as well (Kowalski et al., 20r2; Smith et al., 2008; Wang et al., 2009, in Pečjak and Pirc, 2017, p. 75).

Davis et al. (in Berčnik and Tašner, 2018, p.75) argue that there are different factors that can influence bullying at school, they called them "risk factors" and divided them into three groups, which can be family-based (lack of supervision, lack of clearly established boundaries, social circumstances), school-based (level of tolerance, random staff), dependence on the local community (the degree of crime, dangerous neighborhoods, social imbalance) or they can be of a wider social nature (violence in the media). Tippett and Wolke (2014) conducted a systematic literature review about bullying in connection with socioeconomic status and they found 28 studies that reported the association of socioeconomic status and school bullying. ${ }^{2}$ For example, Due et al. (2009) conducted a study that has shown that students with lower socioeconomic status are more frequently bullied than adolescents from families with higher socioeconomic status.

"The school as an institution has a major role in limiting peer bullying" (Pečjak and Pirc, 2017, p. 74). Students spend a lot of time in class and school is a wider factor that can influence students' behaviour and bullying as well (Farrell et al., 2017, p. 3). Teachers have an important role in class, they can create a class climate that can also affect bullying behaviours and furthermore they can model anti-bullying attitudes which can lead to a decrease of school bullying. (Volk et al., 2016, in Farrell et al., 2017, p. 3).

The school climate and quality of relationships in school can influence students' achievements (Bear et al., 2014, p. 340). In addition, student participation at the school level, the interpersonal climate at school or in the classroom, and the quality of student-teacher relationships and relationships among students themselves are important factors as well (Klemenčič, Mirazchiyski and Novak, 2018, p. 85). ${ }^{3}$ 


\section{Methodology ${ }^{4}$}

This section describes the methodology of the secondary analyses. The main focus of the study is the school bullying of students. The specifics of the study require some clarifications on the measure in focus (school bullying) and the individual background and contextual variables used for testing their association with school bullying.

\section{Data}

This study uses data from the International Civic and Citizenship Education Study (ICCS) 2016. The study was conducted by the International Association for the Evaluation of Educational Achievements (IEA) and in Slovenia, ICCS 2016 was conducted by the Educational Research Institute (ERI). In 1999, when the first cycle was conducted, the study was known by a different name; CivEd. The second and third cycle of the study was in 2009 and 2016, and named ICCS (Klemenčič, Mirazchiyski and Novak, 20r8, p. 6). The study uses national database for secondary analyses. The sample is representative for eighth grade students from Slovenia, meeting the sampling requirements of ICCS. In the national sample of ICCS 2016 2,844 eighth-graders took part in the study (ibid.: p. 26).

The ICCS study "investigates the ways in which young people are prepared to undertake their roles as citizens". In the study, eighth grade students were included in 24 educational systems (Schulz et al., 2016).

In ICCS 20r6, several items were used to construct the Students' Experiences of Physical and Verbal Abuse at School (i.e. bullying) was constructed using data from the following group of statements on how often the students experienced any of the following at school in the last three months (Schulz and Friedman, 2018):

- A student called you by an offensive nickname

- A student said things about you to make others laugh

- A student threatened to hurt you

- You were physically attacked by another student

- A student broke something belonging to you on purpose

- A student posted offensive pictures or text about you on the Internet

Each of the statements has four response categories: "Not at all", "Once", "2 to 4 times", and " 5 times or more". The scaling procedure for constructing the scale used the IRT Generalized Partial Credit Model (GPCM) for estimating the item locations (Schulz and Friedman, 20r8).

4 Summarized from Klemenčič et al. (2019, pp. 140-143); Javornik and Klemenčič (2019, pp. I-2). 
Lower values mean a lower frequency of being bullied and higher values mean a higher frequency of being bullied.

The model used the thresholds between categories. The parameter estimation used the student data from all countries participating in ICCS 2016 where each country was equally weighted, so that all countries provided the same number of students to ensure an equal contribution to the item parameter estimates. The item parameters were then used to compute the individual student scores on the scale using Weighted Likelihood Estimation (WLE). The obtained scores were in logit metric and the final scores were obtained by linearly transforming the original metric to one with a center point of 50 and standard deviation of 10 . The reliability of the scale (Cronbach alpha) for Slovenia is 0.76 (Schulz and Friedman, 2018).

The results of the study can help in the understanding of what are the different forms of bullying (verbal vs. physical) in grade eight. The values on the bullying scale represent the frequency on the experience with different kinds of bullying. The students are sampled as intact classes and the teachers are sampled randomly within the school. The reason for this is that in most countries participating in ICCS, no civic curriculum exists or it is spread across the social science subjects. This means that there is no particular teacher teaching the sampled class of students in civic and citizenship education. The relationship between the students being bullied scale and teacher characteristics and attitudes have to be tested. ICCS teacher data was aggregated on the school level. The categorical teacher variables were aggregated by taking the most frequent response category per variable of interest and assigning it to all the teachers in the school. The resulting variables are then treated as school-level variables.

\section{Method}

In this paper we focus on the following research questions (RQ):

- How the socio-economic status (SES) of students differ based on how often they are bullied?

- How is SES associated with different forms of bullying?

- How is peer violence connected to different contextual factors that can be found in contextual questionnaires?

There are different ways to measure SES, in ICCS it is measured with three variables; the educational level of parents, with their occupation and the third is the number of books that students have at home (Schulz et al., 2018). ICCS 2016 showed an association between a parent's occupation and a student's civic knowledge. The results showed that a student's civ- 
ic knowledge is also connected to the number of books that student has at home. Furthermore there is a connection between civic knowledge and higher education (short-cycle tertiary education (ISCED s) and bachelor or equivalent (ISCED 6)) (Klemenčič, Mirazchiyski and Novak, 20r8, p. 59). Taking into account the findings in the literature and previous research, we expect to find an association between student SES (as defined above) and exposure to peer violence of eighth-graders in Slovenia.

The IEA IDB Analyzer used creates SPSS or SAS syntax that can be used to combine selected files and perform analysis with databases. "It generates SPSS or SAS syntax that takes into account information from the sampling design in the computation of sampling variance, and handles the plausible values" (IDB Analyzer, 2019). We used the IDB Analyzer with SPSS. First, we used merge module in IDB Analyzer to get the data we wanted for Slovenian students in the eighth grade of elementary schools. After that we used the Analysis module of IDB Analyzer to test the association between SES and bullying. We used the data from international Student Questionnaire file.

Linear regression was performed to test the association between bullying ("Students experience of physical and verbal abuse") and with variable "National index of socioeconomic status". The first variable consisted of the variables that define different forms of bullying (see Table 2) and, as we said before, the second variable (SES) was measured with three variables. We also tested the variables on facing different bullying situations separately in association with SES and used a different reference category in several combinations with and without plausible values. Furthermore, we tested the connection between the level of student's civic knowledge and bullying in Slovenia. We divided the variable "National index of socioeconomic status" into three categories to see if there would be any different results.

Further analyses were divided into three parts. The first part tested the relationship between bullying and different individual and family background (e.g. student gender, migration background, family socio-economic status, etc.) and contextual (e.g. school location, school safety, school climate, etc.) variables with being bullied at school. There are two types of background and contextual variables in the data:

I. Categorical, these are Likert-type questions with a fixed number of categories the respondent can choose from as ordinal variables in the data, e.g. "Never", “Sometimes", “Often”, and "Very often”; and 
2. Continuous variables with a ratio or scale level of measurement. These variables were obtained from the responses of sets of questions using IRT (see the previous section for more details).

The analysis of the relationship between the students being bullied and the categorical variables was done by computing the average of the bullying scale for each category a respondent (student, student teachers and school principals) chose. The differences between the means across categories (each mean with each mean) were then tested for statistical significance using multiple dummy coded regression. The report includes results only for those categorical variables in the data which showed significant relationship with being bullied. The table below presents an example using the statement "Most teachers are interested in students' well-being" from ICCS student questionnaire and the bullying scale.

Table I. Differences in the averages of being bullied between categories of "Most teachers are interested in students' well-being", ICCS 2016.

\begin{tabular}{|c|c|c|c|c|c|c|c|c|}
\hline \multirow[b]{2}{*}{ Strongly disagree } & \multicolumn{2}{|c|}{$\begin{array}{l}\text { Strongly } \\
\text { disagree }\end{array}$} & \multicolumn{2}{|c|}{ Disagree } & \multicolumn{2}{|c|}{ Agree } & \multicolumn{2}{|c|}{ Strongly agree } \\
\hline & $\circ$ & & -2.79 & $\checkmark$ & -4.21 & $\nabla$ & -4.36 & $\checkmark$ \\
\hline Disagree & 2.79 & $\Delta$ & $\circ$ & & $-\mathrm{I} .42$ & $\checkmark$ & -1.57 & $\checkmark$ \\
\hline Agree & 4.21 & $\Delta$ & 1.42 & $\Delta$ & $\circ$ & & -0.15 & \\
\hline Strongly agree & 4.36 & $\Delta$ & 1.57 & $\Delta$ & 0.15 & & ० & \\
\hline
\end{tabular}

The first column contains the reference category, i.e. the one against which the comparison groups are compared. The values in the rows represent the differences of the comparison group with the reference group. The values can be compared by row. In this case, students who disagree that most teachers are interested in student well-being have 2.79 score points less on the being bullied scale (-2.79, that is, less frequently bullied) than those who strongly disagree. Those who agree have 4.21 score points lower $(-4.2 \mathrm{I})$ on the bullying scale than those who strongly disagree. Students who strongly agree have 4.46 score points lower $(-4.36)$ on the bullying scale than those who strongly disagree. The black rectangles next to the values pointing up flag higher significant difference of the comparison group. Black rectangles pointing down flag significantly lower difference for the comparison group. No rectangle next to the values indicate that the difference is not statistically significant. For example, students who strongly agree have 0.15 score points (-0.15) lower score on the bullying scale compared to those who agree, but the difference is statistically insignificant besides being rather small. 
The relationship between the bullying at school continuous scale and the other contextual continuous scales was tested using Pearson product-moment correlation. The report presents only the coefficients for those contextual variables which have a statistically significant correlation with the scale on being bullied.

Besides testing which background and contextual variables are related to school bullying, it is also important to test which of the contextual and background characteristics are related to each other. This could indicate which of these variables (I) could have a combined effect on school bullying; and (2) this information could also identify the areas where the educational system can intervene.

This second part of the analysis uses all the variables identified from the first part. However, the number of variables have to be reduced for the following reasons:

I. Some of the background and contextual variables form groups under a single theme (e.g. student perception on the openness of classroom discussion) and are expected to correlate between each other.

2. Many of the variables mentioned in the previous point are part of complex scales and, of course, correlate with them because the complex scales contain the information from these variables.

Thus, the variables which fall within the previous two points were identified and removed in advance from the analyses of the correlations. This way, only variables belonging to different dimensions were used in the analyses of the correlations. It is expected that some correlations will exist between many of the identified variables because many of them are related with the overall context of teaching and learning. Thus, only pairs of variables for which a correlation of at least 0.50 exists were kept in the final results. This way, only the most highly correlated pairs of variables, i.e. the most important ones, were kept. The results are presented in the "Results" section.

The third part of the analysis includes multiple linear regression. The original plan for the multivariate analysis was to use a regression model where the association between a student being bullied at school (dependent variable) and student achievement as its predictor (reading or civic knowledge) when controlling for multiple other variables like SES, school environment security, and student behavioral issues among other background and contextual variables from the student, teacher and school variables. However, although statistically significant, the relationship between bullying and student achievement have shown to be very weak, it is close to zero. Thus, the analysis was changed to test the associ- 
ation between a student being bullied and the groups of variables which have shown the most measures related to school bullying. This means controlling each of the predictors for all other predictors at the same time. It is expected that some of the predictors will lose their predicting power (i.e. their regression coefficients will become insignificant) while others will remain statistically significant. In this way we will be able to identify the most strongly related with the bullying variables after controlling for all others in the model. The results are presented in the "Results" section.

\section{Results ${ }^{5}$}

This study didn't show an association between SES and bullying, which was not expected. We used several combinations of different forms of bullying and the frequency of being abused, but the regression coefficient was low and there was very small or none statistical significance in report.

Slovenia is one of the most egalitarian countries, when it comes to wealth and it has a very low Gini coefficient and that can be one of the reasons why we did not find associations with SES and bullying, which is of course a good thing for Slovenia. The Gini Coefficient is defined as "the relationship of cumulative shares of the population arranged according to the level of equivalised disposable income, to the cumulative share of the equivalised total disposable income received by them" (Eurostat, 20r8). In 2017, Slovenia had a Gini index of 23.7 and in comparison to other EU countries, only Slovakia scored better with 23.2 (ibid.), so there are small differences in Slovenia and it has one of the lowest inequality rates.

The study has shown that students' civic knowledge and bullying at schools are connected in a way that we can assume, students who are abused less often tend to have higher civic knowledge. Those students who score higher in civic knowledge proficiency test tend to be less often victims of school violence. This is an interesting result, although we cannot fully explain it. We can only speculate that, in general, it is possible that students with higher civic knowledge can have the social competences to mitigate situations in which other students attempt bullying them and, thus, avoid being bullied. The ICCS data, however, does not provide any data on student social skills and competences, but the literature shows the connection between social skills and bullying. People who are more socially competent usually has better emotional control and they are also better in solving interpersonal problems with avoiding more conflict and more successful in defending themselves from aggression (Del Prette and Del Prette, 2013, in Silva, 2018, p. 1086). It is important to improve the so-

5 Summarized from Klemenčič et al., 2019, pp. 140-I43; Javornik and Klemenčič, 2019, pp. I-2 and some parts are added. 
Table 2. Percentages of students who reported having the following experience at least once in the past three months.

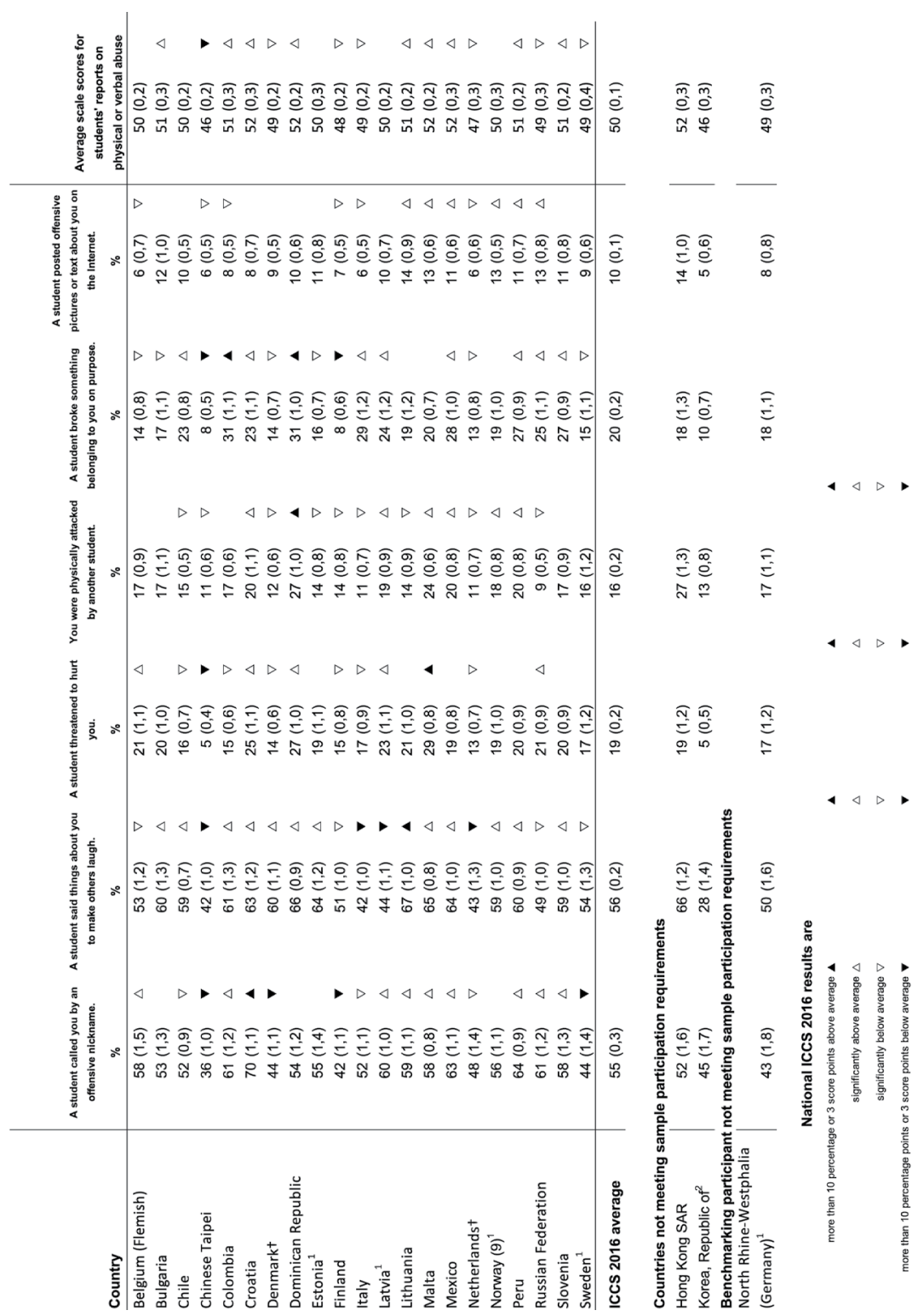

() Standard errors appear in parentheses. Because results are rounded to the nearest whole number, some totals may appear inconsistent.

(9) Country deviated from international defined population and surveyed adjacent upper grade. 
† Met guidelines for sampling paticipation rates only after replacement schools were included.

${ }^{1}$ National Defined Population covers 90\% to 95\% of National Target Population

${ }^{2}$ Country surveyed target grade in the first half of the school year.

Source: Schulz et al., 20I6, p. I57.

Table 3. The forms of bullying to which students were exposed to during the last three months in Slovenia.

\begin{tabular}{|c|c|c|c|c|}
\hline & Not at all & Once & 2 to 4 times & 5 times or more \\
\hline $\begin{array}{l}\text { A student called } \\
\text { you by an offen- } \\
\text { sive nickname. }\end{array}$ & $42.26(\mathrm{I} .28)$ & $24.14(0.84)$ & $17.00(0.91)$ & I6.6I ( 0.82$)$ \\
\hline $\begin{array}{l}\text { A student said } \\
\text { things about you } \\
\text { to make others } \\
\text { laugh. }\end{array}$ & $40.60(0.97)$ & $28.25(0.76)$ & $\mathrm{I} 8.29(0.8 \mathrm{I})$ & $12.85(0.78)$ \\
\hline $\begin{array}{l}\text { A student threat- } \\
\text { ened to hurt you. }\end{array}$ & $80.11(0.86)$ & $11.73(0.62)$ & $5.30(0.45)$ & $2.86(0.3 \mathrm{I})$ \\
\hline $\begin{array}{l}\text { You were physi- } \\
\text { cally attacked by } \\
\text { another student. }\end{array}$ & $83.18(0.85)$ & $10.86(0.69)$ & $3.20(0.4 \mathrm{I})$ & $2.75(0.3 \mathrm{I})$ \\
\hline $\begin{array}{l}\text { A student broke } \\
\text { something be- } \\
\text { longing to you on } \\
\text { purpose. }\end{array}$ & $72.85(0.90)$ & $19.22(0.82)$ & $5.33(0.43)$ & $2.60(0.30)$ \\
\hline $\begin{array}{l}\text { A student posted } \\
\text { offensive pictures } \\
\text { or text about you } \\
\text { on the internet. }\end{array}$ & $88.95(0.79)$ & $7.64(0.63)$ & $1.95(0.26)$ & I. $46(0.25)$ \\
\hline
\end{tabular}

Source: Klemenćič, Mirazchiyski and Novak, 2018, p.92.

cial skills of students who are being victims, and $\gg$ to promote greater social and emotional skills, which can reduce the vulnerability to bullying by facilitating friendships, conflict resolution, emotional self-control and adaptive coping strategies" (Silva et al., 2016; Terroso et al., 2017, in Silva, 2018, p. 1086).

The table above presents the students' answers to the statements related to school bullying from the student questionnaire (the standard errors are in parentheses). In comparison to other participating educational systems, Slovenia is significantly above average in three of the six different forms of bullying ("A student called you by an offensive nickname", "A student said things about you to make others laugh", "A student broke 
something belonging to you on purpose"). Overall, eighth-graders in Slovenia are more likely to report peer violence than the international average. Educational systems with high percentages of reported peer violence are Croatia, the Dominican Republic, Colombia, Lithuania, Malta, Mexico, Peru and Slovenia. The least violence is detected in Chinese Taipei, Finland, Italy, Netherlands, the Russian Federation and Sweden (Klemenčič, Mirazchiyski and Novak, 2018, p. 92).

Table 3 reports the results of experiencing different forms of bullying, for eighth graders from Slovenia. About $28 \%$ of students' reported that they experienced once that another student said things about him/ her to make others laugh, about $18 \%$ were exposed to the same form of bullying two to four times in the last three months prior to data collection. Almost $17 \%$ of eighth-graders experienced five or more times in the last three months (a survey was conducted before summer 2016) being called an offensive nickname by another student. Threats with physical violence, or even physical assault, were less frequent, however, more than $10 \%$ of students experienced threats or physical assault at least once in the last three months. About $19 \%$ of students reported that another student intentionally harmed them at least once in the last three months. A lower rate of reported cyberbullying was also detected. The majority of eighth-graders in Slovenia were not exposed to bullying in the last three months prior to data collection.

Table 4. Frequencies for SES by categories.

\begin{tabular}{|c|c|c|c|c|c|}
\hline $\begin{array}{l}\text { SES by } \\
\text { categories }\end{array}$ & $\mathrm{N}$ of cases & $\begin{array}{c}\text { Sum of } \\
\text { TOTWGTS }\end{array}$ & $\begin{array}{c}\text { Sum of } \\
\text { TOTWGTS } \\
\text { (s.e.) }\end{array}$ & Percent & Percent SE \\
\hline LowSES & 480 & 2954 & I5I,OS & 17,00 & 0,83 \\
\hline Medium SES & 1766 & $1077 \mathrm{I}$ & 294,26 & 61,99 & 1,27 \\
\hline High SES & 598 & 3652 & 268,40 & $21, \mathrm{OI}$ & $\mathrm{I}, 37$ \\
\hline
\end{tabular}

SES has been also divided into three categories, to see, if there would be any differences in results. The divided categories are Low SES, Medium SES and High SES, as Table 4 shows. IDB Analyzer with SPSS was used for computing the frequencies and percentages of students. As we can see from the table above, $62 \%$ of Slovenian eighth-graders belong to the category with medium SES. We computed the means of being bullied at school by the level of SES we categorized (see Table 4). However, the results showed very weak or no statistically significant relationship between SES and bullying. Nevertheless, even if low, violence in schools is 
still present and any level of bullying in a school is too high, so we should therefore work towards decreasing it.

The results from the multiple linear regression (see the "Methodology" section) are presented below. All the results are reported using standardized regression coefficients because the different variables can have different metrics.

Two groups of variables were identified as containing the most variables related to the frequency of a student being bullied: student civic behavior and knowledge, and the school climate (positive school environment). The full list of variables can be found below.

- Student interest in social and political issues (composite scale, student questionnaire)

- Student discussion on political and social issues outside the school (composite scale, student questionnaire)

- Student expected participation in illegal protest activities (composite scale, student questionnaire)

- Student expected participation in legal activities (composite scale, student questionnaire)

- Student expected active political participation (composite scale, student questionnaire)

- Student participation in the wider community (composite scale, student questionnaire)

- Student participation at school (composite scale, student questionnaire)

- Student perception on the importance of personal responsibility for citizenship (composite scale, student questionnaire)

- Student perception of the value of participation at school (composite scale, student questionnaire)

- Student endorsement of gender equality (composite scale, student questionnaire)

- $\quad$ Student positive attitude towards Slovenia (composite scale, student questionnaire)

- Student trust in civic institutions (composite scale, student questionnaire)

- Student engagement with social media (composite scale, student questionnaire)

- Student perception of student interaction at school (composite scale, student questionnaire)

- Student perception of student-teacher relations (composite scale, student questionnaire) 
- Students and teachers taking part in human rights projects (teacher questionnaire)

- Students and teachers visiting political institutions (teacher questionnaire)

- Teacher perception on teacher participation at school (composite scale, teacher questionnaire)

- Teacher perception on their preparedness to teach civic and citizenship topics (composite scale, teacher questionnaire)

- Principal perception of student opportunities to participate in community activities (composite scale, principal questionnaire)

- Principal perception on a student's sense of belonging at school (composite scale, principal questionnaire)

Most of the variables are student-level variables and are related with student participation and attitudes towards different issues. The teacher variables are aggregated on the school level (see the "Methodology" section). Most of the variables in the list are scales. The only exceptions are two of the teacher-level variables. The multiple regression model is presented below.

where

$Y \quad-$ the predicted value of student being bullied

$Y=\beta_{0}+\beta_{1}$ STINT $+\beta_{2}$ STDISC $+\beta_{3}$ STILLEG $+\beta_{4}$ STLEG $+\beta_{5}$ STPOLPART

$+\beta_{6}$ STCOMPART $+\beta_{7} S T S C H L P A R T+\beta_{8} S T R E S P+\beta_{9} S T V A L P A R T$

$+\beta_{10} S T G E N D E N D+\beta_{11}$ STATTSLO $+\beta_{12}$ STTRUST $+\beta_{13}$ STSOCMED

$+\beta_{14}$ STSCHINT $+\beta_{15}$ STTCHREL $+\beta_{16}$ STTCHHUM $+\beta_{17}$ STTCHVIS

$+\beta_{18}$ TCHPART $+\beta_{19}$ TCHPREP $+\beta_{20}$ PRSTPART $+\beta_{21}$ PRSTBEL $+e$

$\beta_{0} \quad-$ the model constant

$\beta_{1}-\beta_{21} \quad-$ the regression coefficients for the variables listed below

STINT - student interest in social and political issues

STDISC - student discussion on political and social issues outside the school

STILLEG - student expected participation in illegal protest activities

STLEG - student expected participation in legal activities

STPOLPART - student expected active political participation

STCOMPART - student participation in the wider community

STSCHLPART - student participation at school

STRESP - student perception on the importance of personal responsibility for citizenship

STVALPART - student perception of the value of participation at school

STGENDEND - student endorsement of gender equality

STATTSLO - student positive attitude towards Slovenia 
STTRUST - student trust in civic institutions

STSOCMED - student engagement with social media

STSCHINT - student perception of student interaction at school

STTCHREL - student perception of student-teacher relations

STTCHHUM - students and teachers taking part in human rights projects

STTCHVIS - students and teachers visiting political institutions

TCHPART - teacher perception on teacher participation at school

TCHPREP - teacher perception on their preparedness to teach civic and citizenship topics

PRSTPART - principal perception of student opportunities to participate in community activities

PRSTBEL - principal perception on students' sense of belonging at school

e

- the model error

The results from the multiple linear regression model are presented in the next table. As the results show, the regression coefficients of six variables remain statistically significant even after controlling for each one of the remaining variables. These are the expected student participation in illegal protest activities, the student participation in the wider community, student participation at school, student trust in civic institutions, student interaction at school, and the principal perceptions on student opportunity to participate in community activities. All of these variables are related to student participation (current or future). This is an important finding. Perhaps increasing student participation or preparing them for the future participation could help alleviate the frequency of bullying.

Table 5. Results from the multiple linear regression model of bullying, ICCS 2016.

\begin{tabular}{lllll}
\multicolumn{1}{c}{ Variable } & $\begin{array}{c}\text { Standardized } \\
\text { regression coefficient } \\
\text { (SE) }\end{array}$ & Sig. \\
$\begin{array}{l}\text { Student interest in social and political issues (composite scale, } \\
\text { student questionnaire) }\end{array}$ & -0.01 & $(0.02)$ & - \\
\hline $\begin{array}{l}\text { Student discussion on political and social issues outside the } \\
\text { school (composite scale, student questionnaire) }\end{array}$ & 0.04 & $(0.03)$ & - \\
$\begin{array}{l}\text { Student expected participation in illegal protest activities } \\
\text { (composite scale, student questionnaire) }\end{array}$ & 0.07 & $(0.03)$ & * \\
\hline $\begin{array}{l}\text { Student expected participation in legal activities (composite } \\
\text { scale, student questionnaire) }\end{array}$ & 0.03 & $(0.02)$ & - \\
\hline $\begin{array}{l}\text { Student expected active political participation (composite } \\
\text { scale, student questionnaire) }\end{array}$ & 0.01 & $(0.02)$ & - \\
\hline
\end{tabular}




\section{Variable}

Standardized

regression coefficient Sig. (SE)

Student participation in the wider community (composite scale, student questionnaire)

0.08

$(0.02)$

Student participation at school (composite scale, student questionnaire)

Student perception on the importance of personal responsibility for citizenship (composite scale, student questionnaire)

Student perception of the value of participation at school (composite scale, student questionnaire)

Student endorsement of gender equality (composite scale, student questionnaire)

Student positive attitude towards Slovenia (composite scale, student questionnaire)

Student trust in civic institutions (composite scale, student questionnaire)

Student engagement with social media (composite scale, student questionnaire)

Student perception of student interaction at school (composite scale, student questionnaire)

Student perception of student-teacher relations (composite scale, student questionnaire)

Students and teachers taking part in human rights projects (teacher questionnaire)

Students and teachers visiting political institutions (teacher questionnaire)

Teacher perception on teacher participation at school (composite scale, teacher questionnaire)

Teacher perception on their preparedness to teach civic and citizenship topics (composite scale, teacher questionnaire)

Principal perception of student opportunities to participate in community activities (composite scale, principal questionnaire)

Principal perception on students' sense of belonging at school (composite scale, principal questionnaire)

* Statistically significant $(p<0.05)$

The model explains $\mathbf{2} \%$ of the variance in the frequency of the student being bullied.

\section{Conclusion}

The research has shown associations between SES and bullying. However, our study did not find any statistical significant relationship between these variables. One of the possible explanations could be that Slovenia, according to the Gini Index or Gini Coefficient, seems to be a very egal- 
itarian society, and there are no major differences in the dispersion of income and wealth. Based on our SES variable, the majority of eighth grade students in Slovenia belong to the middle category with medium socioeconomic status. Findings of the study indicate that students with lower socioeconomic status do not tend to be more frequently subjected to peer violence than those students that live in families with higher economic status. Even if this is good news for us, school violence is still very present in schools around Slovenia.

Multiple linear regression has shown that there are some variables that seem to be connected to bullying and peer violence. All of them are related to current and future (anticipated) participation of the students (expected student participation in illegal protest activities, the student participation in the wider community, student participation at school, student trust in civic institutions, student interaction at school, and the principal perceptions on student opportunity to participate in community activities). We can assume that student participation or preparing them for the future participation could reduce the frequency of bullying in school, which is an important finding.

An important goal for education is to establish a safe and stimulating learning environment which is necessary for all students regardless of their race, ethnicity, gender or SES. Peer violence and bullying can have terrible and long-lasting consequences, and this is why more research on violence among students is needed. The topic can be further investigated as an important determinant of school climate. This study is a small contribution to researching peer violence, and there are needs for further studies as all violence should be well investigated as well as the background of it in order to contribute to the policies which can prevent these things from happening.

\section{Literature}

Bear, G. G., Yang, C., Pell, M., and Gaskins, C. (2014) Validation of a brief measure of teacher's perceptions of school climate: relations to student achievement and suspensions. Learning Environments Research 17(3), pp. 339-354.

Berčnik, S., and Tašner, V. (2018). School and violence. Ars \& humanitas: revija za umetnost in humanistiko $\mathrm{I} 2(\mathrm{I}), \mathrm{pp} .73-87$.

Daniels, J. A. (2017) Bullying and School Violence Interventions. In Levesque, R. J. R. (ed.), Encyclopedia of Adolescence, pp. I-7. https:// doi.org/10.1007/978-3-319-32132-5_376-2 (I2.10.2019). 
Dorio, N. B., Clark, K. N., Demaray, M. K., and Doll, E. M. (2019) School Climate Counts: A Longitudinal Analysis of School Climate and Middle School Bullying Behaviors. International Journal of Bullying Prevention. https://doi.org/10.1007/s42380-019-00038-2 (4.11.2019).

Due, P., Merlo, J., Harel-Fisch, Y., Damsgaard, M. T., Holstein, B. E., and Lynch, J. (2009) Socioeconomic Inequality in Exposure to Bullying During Adolescence: A Comparative, Cross-Sectional, Multilevel Study in 35 Countries. American Journal of Public Health. 99(5), pp. 907-914. https://doi.org/10.2105/AJPH.2008.139303 (13.10.2019).

Farrell, A. H., Schiralli, K. N., and Volk, A. A. (2017). Factors That Influence Bullying. In Shackelford, T. K., and Weekes-Shackelford, V. A. (eds.), Encyclopedia of Evolutionary Psychological Science, pp. I-5. https://doi.org/10.1007/978-3-319-16999-6_162-I (13.10.2019).

IDB Analyzer. Help Manual for the IEA IDB Analyzer (Version 4.0). (2019). International Association for the Evaluation.

Javornik, Š. and Klemenčič, E. (2019) Peer violence in the eighth grade of elementary schools in Slovenia: Association between peer violence and socio-economic status. In Dermol, V. (ed.), Thriving on Future Education, Industry, Business and Society: Proceedings of the MakeLearn and TIIM International Conference, p. 20). http://www.toknowpress.net/ ISBN/978-96I-6914-25-3/MakeLearn2019.pdf (I0.10.2019).

Klemenčič, E., Mirazchiyski, P., and Novak, J. (2018). Nacionalno poročilo Mednarodne raziskave državljanske vzgoje in izobraževanja (IEA ICCS 20I6). https://www.researchgate.net/publication/328413742_ Nacionalno_porocilo_Mednarodne_raziskave_drzavljanske_vzgoje_ in_izobrazevanja_IEA_ICCS_2016 (I0.12.2019).

Kristančič, A. (2002) Socializacija agresije. Ljubljana: AA Inserco.

Merrell, K. W., Gueldner, B. A., Ross, S. W., and Isava, D. M. (2008) How effective are school bullying intervention programs? A meta-analysis of intervention research. School Psychology Quarterly 23(I), pp. 26-42. https://doi.org/10.1037/1045-3830.23.1.26 (I 4.10.2019).

Olweus, D. (1997) Bully/victim problems in school: Facts and intervention. European Journal of Psychology of Education, I2, pp. 495-510. https:// doi.org/10.1007/BF03172807 (II.10.2019).

Pečjak, S. (2014) Medvrstniško nasilje v šoli. Ljubljana: Univerza v Ljubljani, Filozofska fakulteta.

Pečjak, S., and Pirc, T. (2017) School climate in peer bullying: Observers' and active participants' perceptions. Psihološka Obzorja / Horizons of Psychology. 26, pp. 74-82. https://doi.org/10.20419/2017.26.470 (12.10.2019). 
Schulz, W., and Friedman, T. (2018) Scaling Procedures for ICCS Questionnaire Items. In Schulz, W., Losito, B., Carstens, R., and Fraillon, J. (eds.), ICCS 2016 Technical Report, pp. 139-244. Amsterdam: International Association for the Evaluation of Educational Achievement.

Schulz, W., Losito, B., Carstens, R., and Fraillon, J. (eds.). (2018) ICCS 2016 Technical Report. Amsterdam: International Association for the Evaluation of Educational Achievement.

Sullivan, K. (2011) The anti-bullying handbook. London: Oxford University Press.

Silva, J., Oliveira, W., Carlos, D., Lizzi, E., Rosário, R., and Silva, M. (2018) Intervention in social skills and bullying. Revista Brasileira de Enfermagem, 7I, pp. 1085-I091. https://doi.org/10.1590/0034-7167-2017-015I (28.10.2019).

Tippett, N., and Wolke, D. (2014) Socioeconomic Status and Bullying: A Meta-Analysis. American Journal of Public Health ro4(6), pp. 4859. https://www.ncbi.nlm.nih.gov/pmc/ articles/PMC4061998/ (I5.10.2019). 